\title{
CSF orexin-A levels after rituximab treatment in recent onset narcolepsy type 1
}

Pontus Wasling, MD, PhD, Clas Malmeström, MD, PhD, and Kaj Blennow, MD, PhD

Neurol Neuroimmunol Neuroinflamm 2019;6:e613. doi:10.1212/NXI.0000000000000613

\author{
Correspondence \\ Dr. Wasling \\ pontus.wasling@gu.se
}

\section{Case presentation}

A 28-year-old man with narcolepsy type 1 (NT1) was referred due to excessive daytime sleepiness starting 5 months earlier, and 2 months prior to his admission, he had 1 to 3 daily cataplexies related to laughter, anger, and surprise, leading to a loss of muscle tone in the face, neck, and legs. Inquiries with Epworth Sleepiness Scale (ESS) was initially 21 of 24 points. Prior to admission, his medical history was insignificant, and physical examination did not show any neurologic deficits.

A lumbar puncture was performed soon after his first admission with overall normal findings in the CSF. This included absence of pleocytosis and normal levels of glucose, lactate, albumin, immunoglobulin $\mathrm{G}$ and immunoglobulin $\mathrm{M}$. These samples were also normal in the subsequent lumbar punctures. Cytology showed activated lymphocytes with varied size in the first but not in the following lumbar punctures. No selective oligoclonal bands in CSF could be found. The first CSF orexin-A, measured with an in-house method, ${ }^{1}$ was pathologic at $105 \mathrm{pg} / \mathrm{mL}$. To reassure that orexin-A was pathologically low, a second lumbar puncture was performed within 2 weeks with a similar level $(100 \mathrm{pg} / \mathrm{mL})$.

Multiple Sleep Latency Test was performed 4 weeks after the first rituximab treatment and showed a shortened sleep latency of 2.5 minutes, but did not show any ( 0 out of 5) sleep onset REM periods. He was HLA-DQB1 $1^{*} 06: 02$ positive.

It has recently been suggested that rituximab treatment might be an interesting treatment option in NT1, as it induces transient immunosuppression of B cells with a potential effect on the presumed autoimmune etiology. ${ }^{2}$ Therefore, the patient was deemed eligible for rituximab treatment, which was initiated approximately 6 months after symptom onset. The patient was placed on rituximab 1,000 mg. CD19 and CD20 were measured before treatment and after 6 months, with a decrease from 0.11 and $0.9 \times 10 \mathrm{e} 9 / \mathrm{L}$ to $<0.01$ and $0.03 \times 10 \mathrm{e} 9 / \mathrm{L}$, indicating a depleting effect of rituximab on the B-cell population. Rituximab treatment was repeated at 6-month intervals, with no other treatment offered during this period.

To evaluate an improvement in orexinergic nerve cell function, lumbar puncture was performed after 3, 5, 12, 14, 18, and 26 months to measure orexin-A in CSF. The measurements did not show any improvement in orexin-A levels, but rather a further decrease from 105 (106) and 100 to 77, 79,65 (70), 64 (80), 68, and $72(60) \mathrm{pg} / \mathrm{mL}$ after rituximab treatment (figure), with measurements from frozen samples reanalyzed in 1 run within parenthesis. However, the patient reported a transient improvement on subjective sleepiness during approximately 1 month after rituximab treatment after all 4 treatments. Sleepiness was measured using ESS in conjunction to lumbar punctures and approximately 1 month after each treatment with rituximab. At all time points, the ESS score was $16-17$, i.e., somewhat lower than the initially measured score. There was no change in the frequency of self-reported cataplexies during the follow-up.

From the Department of Clinical Neuroscience (P.W., C.M.), Institute of Neuroscience and Physiology, Sahlgrenska Academy at the University of Gothenburg, Gothenburg, Sweden; and Department of Psychiatry and Neurochemistry (K.B.), Institute of Neuroscience and Physiology, Sahlgrenska Academy at the University of Gothenburg, Mölndal, Sweden. 
Figure Repeated measurements of CSF-orexin in recent onset NT1

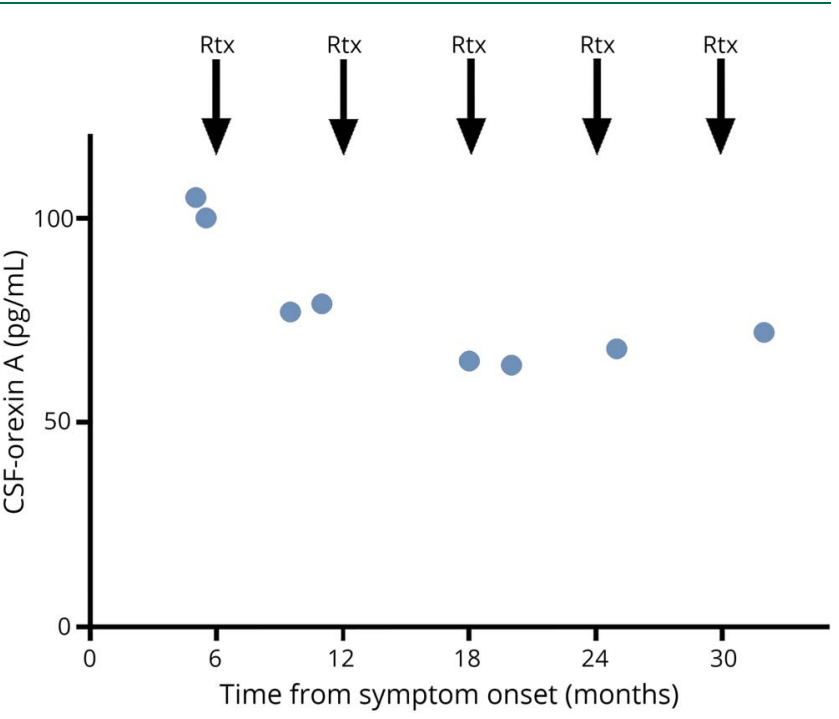

Longitudinal measurements of CSF-orexin A during repeated 1,000 mg rituximab infusions as indicated by arrows. NT1 = narcolepsy type 1 .

\section{Discussion}

We report that repeated rituximab treatment in a patient with new onset NT1 did not result in increased levels of CSF orexin-A. On the contrary, the level of this transmitter substance further decreased from 100 to around $60 \mathrm{pg} / \mathrm{mL}$. We could not detect any increase in the levels of orexin-A that corresponded to the transient subjective amelioration around 1 month after rituximab treatment.

The reason why immunomodulatory treatment was not effective in this case could have several explanations. First, destruction of hypothalamic orexin-producing neurons could be cell mediated through cytotoxicity without the involvement of B cells. If that is the case, depletion of B cells would not affect the development of narcolepsy. Although higher frequency of antibodies directed against neuronal structures such as tribbles homologue $2^{3,4}$ have been shown in newly diagnosed narcolepsy patients, no causal role for these antibodies has been demonstrated. The lack of oligoclonal bands in CSF, together with findings that suggest a $\mathrm{T}$ cell-mediated cytotoxic etiology ${ }^{5}$ also strengthens the hypothesis that $B$ cells are not primarily involved in the destruction of hypothalamic neurons. Another possible reason is that the treatment was initiated to late in the progress of the disease. Animal experiment using conditional ablation of orexin neurons in hypothalamus shows that $95 \%$ orexin neuron loss is necessary to trigger cataplexy, ${ }^{6}$ suggesting that only a small fraction of orexinergic neurons were viable when treatment started.

Finding an immunomodulatory treatment that prevents or reverses the development of cell death in narcolepsy would be of great importance, but treatment with a substance acting to reduce $\mathrm{T}$ cell-mediated destruction of hypothalamic neurons could be a more favorable option.

\section{Study funding}

Fredrik and Ingrid Thuring's Foundation.

\section{Disclosure}

P. Wasling, C. Malmeström, and K. Kaj Blennow report no disclosures. Go to Neurology.org/NN for full disclosures.

\section{Publication history}

Received by Neurology: Neuroimmunology \& Neuroinflammation March 19, 2019. Accepted in final form August 5, 2019.

\section{Appendix Authors}

\begin{tabular}{lll}
\hline Name & Location & Contribution \\
\hline $\begin{array}{l}\text { Pontus } \\
\text { Wasling, MD, } \\
\text { PhD }\end{array}$ & $\begin{array}{l}\text { University of } \\
\text { Gothenburg }\end{array}$ & $\begin{array}{l}\text { Data acquisition, drafting/revising the } \\
\text { manuscript, study concept or design, } \\
\text { analysis or interpretation of data, } \\
\text { acquisition of data, study supervision }\end{array}$ \\
\hline $\begin{array}{l}\text { Clas } \\
\text { Malmeström, } \\
\text { MD, PhD }\end{array}$ & $\begin{array}{l}\text { Gniversity of } \\
\text { Gothenburg }\end{array}$ & $\begin{array}{l}\text { Drafting/revising the manuscript, study } \\
\text { concept or design, analysis or } \\
\text { interpretation of data, statistical } \\
\text { analysis }\end{array}$ \\
\hline $\begin{array}{l}\text { Kaj Blennow, } \\
\text { MD, PhD }\end{array}$ & $\begin{array}{l}\text { University of } \\
\text { Gothenburg }\end{array}$ & $\begin{array}{l}\text { Drafting/revising the manuscript, } \\
\text { acquisition of data }\end{array}$ \\
\hline
\end{tabular}

\section{References}

1. Portelius E, Soininen H, Andreasson U, et al. Exploring Alzheimer molecular pathology in Down's syndrome cerebrospinal fluid. Neurodegener Dis 2014;14 98-106.

2. Sarkanen T, Alen R, Partinen M. Transient impact of rituximab in H1N1 vaccinationassociated narcolepsy with severe psychiatric symptoms. Neurologist 2016;21:85-86.

3. Toyoda H, Tanaka S, Miyagawa T, et al. Anti-tribbles homolog 2 autoantibodies in Japanese patients with narcolepsy. Sleep 2010;33:875-878.

4. Cvetkovic-Lopes V, Bayer L, Dorsaz S, et al. Elevated Tribbles homolog 2-specific antibody levels in narcolepsy patients. J Clin Invest 2010;120:713-719.

5. Latorre D, Kallweit U, Armentani E, et al. T cells in patients with narcolepsy target self-antigens of hypocretin neurons. Nature 2018;562:63-68.

6. Tabuchi S, Tsunematsu T, Black SW, et al. Conditional ablation of orexin/hypocretin neurons: a new mouse model for the study of narcolepsy and orexin system function. J Neurosci 2014;34:6495-6509. 


\section{Neurology \\ Neuroimmunology \& Neuroinflammation}

\section{CSF orexin-A levels after rituximab treatment in recent onset narcolepsy type 1 Pontus Wasling, Clas Malmeström and Kaj Blennow \\ Neurol Neuroimmunol Neuroinflamm 2019;6; \\ DOI 10.1212/NXI.0000000000000613}

This information is current as of September 4, 2019

\section{Updated Information \& Services}

References

Subspecialty Collections

Permissions \& Licensing

\section{Reprints}

including high resolution figures, can be found at: http://nn.neurology.org/content/6/6/e613.full.html

This article cites 6 articles, 1 of which you can access for free at: http://nn.neurology.org/content/6/6/e613.full.html\#\#ref-list-1

This article, along with others on similar topics, appears in the following collection(s):

Autoimmune diseases

http://nn.neurology.org//cgi/collection/autoimmune_diseases

Narcolepsy

http://nn.neurology.org//cgi/collection/narcolepsy

Information about reproducing this article in parts (figures,tables) or in its entirety can be found online at:

http://nn.neurology.org/misc/about.xhtml\#permissions

Information about ordering reprints can be found online:

http://nn.neurology.org/misc/addir.xhtml\#reprintsus

Neurol Neuroimmunol Neuroinflamm is an official journal of the American Academy of Neurology.

Published since April 2014, it is an open-access, online-only, continuous publication journal. Copyright

Copyright $\odot 2019$ The Author(s). Published by Wolters Kluwer Health, Inc. on behalf of the American Academy of Neurology.. All rights reserved. Online ISSN: 2332-7812.

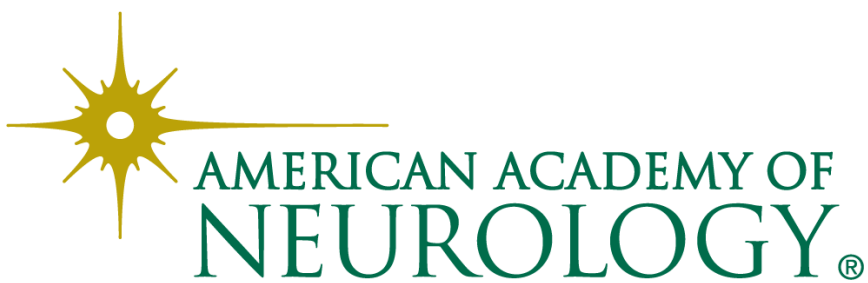

